\title{
VISUALIZATION OF THE EFFECT OF UPFC ON POWER FLOW CHARACTERESTICS
}

\author{
A. Ahmed \\ Electrical Engineering Department, Faculty of Engineering, Assiut \\ University, Assiut,Egypt E-mail: a_ahmed@aun.edu.eg
}

(Received March 27, 2007 Accepted, April 3, 2007)

\begin{abstract}
This paper presents an investigation and visualization of the effect of UPFC on power flow characteristics by incorporating it in a simple twobus system. The UPFC is represented by two ideal voltage sources each of them is connected in series with a reactance. This model investigates the nonlinearity of UPFC on the power system load flow problem. Since the various UPFC variables equations are non-linear, a form of vector presentation in complex power plane is used to visualize the effect of different control variables of UPFC on line power transfer. This visualization helps to identify the effectiveness of each one of control variables on power control region.
\end{abstract}

KEYWORDS: Flexible AC transmission systems (FACTS), Unified power flow controller (UPFC), Load flow analysis, MATLAB.

\section{INTRODUCTION}

The Unified Power Flow Controller (UPFC) was proposed [1] for real-time control and dynamic compensation of AC transmission systems, providing the necessary functional flexibility required to solve many of the problems facing the utility industry. The UPFC consists of two switching converters, which in the implementations considered are voltage-sourced inverters using gate turn-off (GTO) thyristor valves, as illustrated in Fig. 1 [1-2]. These inverters, labeled "Inverter 1" and "Inverter 2" in the figure, are operated from a common DC link provided by a DC storage capacitor. This arrangement functions as an ideal $\mathrm{AC}$-to-AC power converter in which the real power can freely flow in either direction between the two terminals of the two inverters and each inverter can independently generate (or absorb) reactive power at its own AC output terminal. Inverter 2 provides the main function of the UPFC by injecting an AC voltage $\mathrm{V}_{\text {ser }}$ with controllable magnitude $\left(0 \leq \mathrm{V}_{\text {ser }} \leq \mathrm{V}_{\text {ser max }}\right)$ and phase angle $\theta_{\text {ser }}\left(0 \leq \theta_{\text {ser }} \leq 360^{\circ}\right)$, at the power frequency, in series with line via an insertion transformer. This injected voltage can be considered essentially as a synchronous voltage source [2-5]. The transmission line current flows through this voltage source resulting in real and reactive power exchange between it and the $\mathrm{AC}$ system. The real power exchanged at the AC terminal is converted by the inverter into DC power, which appears at the DC link as positive or negative real power demand. The reactive power exchanged at the AC terminal is generated internally by the inverter. 
The basic function of inverter 1 is to supply or absorb the real power demanded by inverter 2 at the common DC link. This DC link power is converted back to AC and coupled to the transmission line via a shunt-connected transformer.

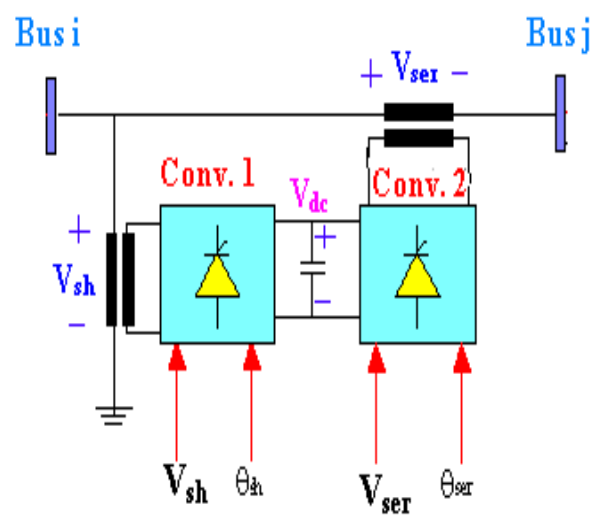

Fig. (1): UPFC basic structure.

Inverter 1 can also generate or absorb controllable reactive power, if it is desired, and thereby it can provide independent shunt reactive compensation for the line. It is important to note that whereas there is a closed "direct" path for the real power negotiated by the action of series voltage injection through inverters 1 and 2 back to the line, the corresponding reactive power exchanged is supplied or absorbed locally by inverter 2 and therefore it does not flow through the line. Thus, inverter 1 can be operated at a unity power factor or be controlled to have a reactive power exchange with the line independently of the reactive power exchanged by inverter 2 . This means that there is no continuous reactive power flow through the UPFC.

\section{STEADY-STATE CHARACTERISTICS OF UPFC}

A power transmission system composed of a line equipped with UPFC can adequately demonstrate basic characteristics of the UPFC for steady-state conditions. Fig. (2) shows a single-phase equivalent circuit of such a system [6-7]. The line is connected between two voltage buses $\mathrm{V}_{1} \angle \delta_{1}$ and $\mathrm{V}_{2} \angle \delta_{2}$. The UPFC is represented by an ideal series voltage and shunt voltage source each connected with a series reactance. Series

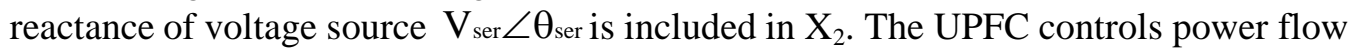
of the line through continuous control of $\mathrm{V}_{\text {ser }}$ and $\theta_{\text {ser }}$. Depending upon the system operating conditions, voltage source $\mathrm{V}_{\mathrm{ser}} \angle \theta_{\text {ser }}$ exchanges real and reactive power with the system. Since a UPFC can neither absorb nor deliver real power (losses are neglected), phase angle $\theta_{\text {sh }}$ is adjusted to compensate for real power exchange between $\mathrm{V}_{\text {sh }} \angle \theta_{\text {sh }}$ and the system. $\mathrm{V}_{\text {sh }}$ can be adjusted to compensate for the reactive power exchange between $\mathrm{V}_{\mathrm{ser}} \angle \theta_{\text {ser }}$ and the system. In general, by means of controlling $\mathrm{V}_{\mathrm{sh}}$, the net reactive power exchange between the UPFC and the system can be regulated [7]. 
In order to visualize the effect of the UPFC control variables, $\left(\mathrm{V}_{\mathrm{ser}}, \theta_{\mathrm{ser}}, \mathrm{V}_{\mathrm{sh}}\right.$, and $\theta_{\text {sh }}$, on the power flow characteristics, it is required to obtain expressions for sendingend and receiving-end powers as a function of these control variables, this can be achieved as follow:

Applying KCL and KVL to the system of Fig. (2), to obtain the system current components.

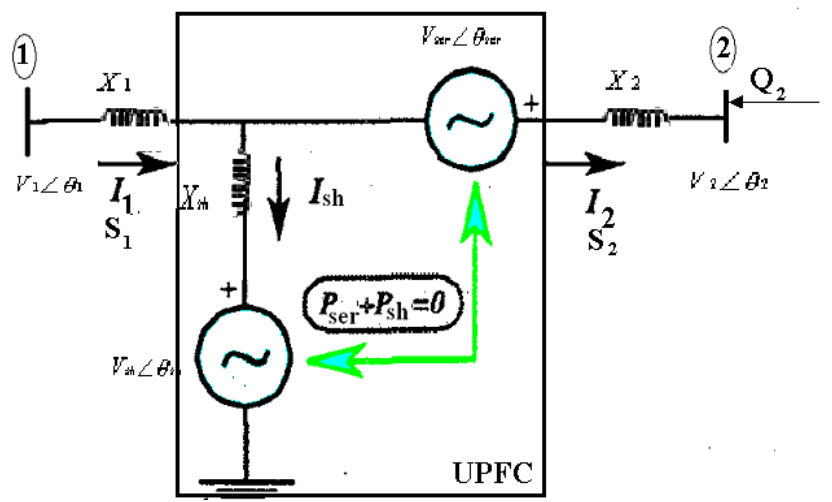

Fig. (2): Single-line diagram of transmission line and UPFC

$$
\begin{aligned}
& \mathrm{I}_{1}=\mathrm{I}_{2}+\mathrm{I}_{\mathrm{sh}} \\
& \mathrm{V}_{1} \angle \delta_{1}=\mathrm{j} X_{1} \mathrm{I}_{1}+\mathrm{j} X_{\mathrm{sh}} \mathrm{I}_{\mathrm{sh}}+\mathrm{V}_{\mathrm{sh}} \angle \theta_{\mathrm{sh}} \\
& \mathrm{V}_{2} \angle \delta_{2}+\mathrm{V}_{\mathrm{ser}} \angle \theta_{\text {ser }}=\mathrm{j} X_{2} \mathrm{I}_{2}+\mathrm{j} X_{\mathrm{sh}} \mathrm{I}_{\mathrm{sh}}+\mathrm{V}_{\mathrm{sh}} \angle \theta_{\mathrm{sh}}
\end{aligned}
$$

By substitution of $I_{s h}$ from equation (1) into equations (2) and (3), it is possible to get two equations in two unknowns, $\mathrm{I}_{1}, \mathrm{I}_{2}$ as equation (4) illustrate.

$$
\begin{gathered}
\mathrm{j}\left[\begin{array}{ll}
\mathrm{X}_{1}+\mathrm{X}_{\mathrm{sh}} & -\mathrm{X}_{\mathrm{sh}} \\
\mathrm{X}_{\mathrm{sh}} & -\left(\mathrm{X}_{2}+\mathrm{X}_{\mathrm{sh}}\right)
\end{array}\right]\left[\begin{array}{l}
\mathrm{I}_{1} \\
\mathrm{I}_{2}
\end{array}\right]= \\
{\left[\begin{array}{l}
\mathrm{V}_{1} \angle \delta_{1}-\mathrm{V}_{\mathrm{sh}} \angle \theta_{\mathrm{sh}} \\
\mathrm{V}_{2} \angle \delta_{2}-\mathrm{V}_{\mathrm{ser}} \angle \theta_{\mathrm{ser}}-\mathrm{V}_{\mathrm{sh}} \angle \theta_{\mathrm{sh}}
\end{array}\right]}
\end{gathered}
$$

Solving the above linear algebraic equation, (4), it is possible to obtain $\mathrm{I}_{1}$ and $\mathrm{I}_{2}$.

$$
\begin{aligned}
& \mathrm{I}_{1}=\frac{1}{\mathrm{X}_{\mathrm{t}}^{2} \angle 90}\left[\begin{array}{l}
\left(\mathrm{X}_{\mathrm{sh}}+\mathrm{X}_{2}\right) \mathrm{V}_{1} \angle \delta_{1}-\mathrm{X}_{2} \mathrm{~V}_{\mathrm{sh}} \angle \theta_{\mathrm{sh}} \\
+\mathrm{X}_{\mathrm{sh}} \mathrm{V}_{\mathrm{ser}} \angle \theta_{\mathrm{ser}}-\mathrm{X}_{\mathrm{sh}} \mathrm{V}_{2} \angle \delta_{2}
\end{array}\right] \\
& \mathrm{I}_{2}=\frac{1}{\mathrm{X}_{\mathrm{t}}^{2} \angle 90}\left[\begin{array}{l}
\mathrm{X}_{\mathrm{sh}} \mathrm{V}_{1} \angle \delta_{1}+\mathrm{X}_{1} \mathrm{~V}_{\mathrm{sh}} \angle \theta_{\text {sh }} \\
+\left(\mathrm{X}_{\mathrm{sh}}+\mathrm{X}_{1}\right) \mathrm{V}_{\mathrm{ser}} \angle \theta_{\text {ser }}-\left(\mathrm{X}_{\mathrm{sh}}+\mathrm{X}_{\mathrm{l}}\right) \mathrm{V}_{2} \angle \delta_{2}
\end{array}\right]
\end{aligned}
$$

From equations (5) and (6) it is possible to obtain $I_{\text {sh }}$ by substitution in equation (1)

$$
\mathrm{I}_{\mathrm{sh}}=\frac{1}{\mathrm{X}_{\mathrm{t}}^{2} \angle 90}\left[\begin{array}{l}
\mathrm{X}_{2} \mathrm{~V}_{1} \angle \delta_{1}-\left(\mathrm{X}_{1}+\mathrm{X}_{2}\right) \mathrm{V}_{\mathrm{sh}} \angle \theta_{\mathrm{sh}} \\
-\mathrm{X}_{1} \mathrm{~V}_{\mathrm{ser}} \angle \theta_{\mathrm{ser}}+\mathrm{X}_{1} \mathrm{~V}_{2} \angle \delta_{2}
\end{array}\right]
$$

Where $X_{t}=X_{1} X_{2}+X_{1} X_{s h}+X_{2} X_{\text {sh }}$. 
After obtaining the system current components and UPFC shunt current, it is possible to get expressions for the sending-end, receiving-end and UPFC powers as follow:

The sending-end power $S_{1}$ can be expressed as:

$$
\begin{aligned}
& \mathrm{S}_{1}=\mathrm{P}_{1}+\mathrm{j}_{1}=\mathrm{V}_{1} \mathrm{I}_{1}^{*}=\frac{\left(\mathrm{X}_{\mathrm{sh}}+\mathrm{X}_{2}\right) \mathrm{V}_{1}{ }^{2}}{\mathrm{X}_{\mathrm{t}}^{2}} \angle 90 \\
& -\frac{\mathrm{X}_{\mathrm{sh}} \mathrm{V}_{1} \mathrm{~V}_{2}}{\mathrm{X}_{\mathrm{t}}{ }^{2}} \angle\left(90+\delta_{1}-\delta_{2}\right)-\frac{\mathrm{X}_{\mathrm{t}} \mathrm{X}_{1} \mathrm{~V}_{\mathrm{sh}}}{\mathrm{X}_{\mathrm{t}}{ }^{2}} \angle\left(90+\delta_{1}-\theta_{\mathrm{sh}}\right) \\
& +\frac{\mathrm{X}_{\mathrm{sh}} \mathrm{V}_{1} \mathrm{~V}_{\text {ser }}}{\mathrm{X}_{\mathrm{t}}^{2}} \angle\left(90+\delta_{1}-\theta_{\text {ser }}\right) \\
& \mathrm{P}_{1}=\frac{\mathrm{X}_{\mathrm{sh}} \mathrm{V}_{1} \mathrm{~V}_{2}}{\mathrm{X}_{\mathrm{t}}^{2}} \sin \left(\delta_{1}-\delta_{2}\right)+\frac{\mathrm{X}_{2} \mathrm{~V}_{1} \mathrm{~V}_{\mathrm{sh}}}{\mathrm{X}_{\mathrm{t}}^{2}} \sin \left(\delta_{1}-\theta_{\mathrm{sh}}\right) \\
& -\frac{\mathrm{X}_{\mathrm{sh}} \mathrm{V}_{1} \mathrm{~V}_{\text {ser }}}{\mathrm{X}_{\mathrm{t}}^{2}} \sin \left(\delta_{1}-\theta_{\text {ser }}\right) \\
& \mathrm{Q}_{1}=\frac{\left(\mathrm{X}_{\mathrm{sh}}+\mathrm{X}_{2}\right) \mathrm{V}_{1}^{2}}{\mathrm{X}_{\mathrm{t}}^{2}}-\frac{\mathrm{X}_{\mathrm{sh}} \mathrm{V}_{1} \mathrm{~V}_{2}}{\mathrm{X}_{\mathrm{t}}^{2}} \cos \left(\delta_{1}-\delta_{2}\right)- \\
& \frac{\mathrm{X}_{2} \mathrm{~V}_{1} \mathrm{~V}_{\mathrm{sh}}}{\mathrm{X}_{\mathrm{t}}{ }^{2}} \cos \left(\delta_{1}-\theta_{\mathrm{sh}}\right)+\frac{\mathrm{X}_{\mathrm{sh}} \mathrm{V}_{1} \mathrm{~V}_{\text {ser }}}{\mathrm{X}_{\mathrm{t}}^{2}} \cos \left(\delta_{1}-\theta_{\text {ser }}\right)
\end{aligned}
$$

The receiving-end power can be expressed as:

$$
\begin{aligned}
& \mathrm{S}_{2}=\mathrm{P}_{2}-\mathrm{jQ}_{2}=\mathrm{V}_{2} \mathrm{I}_{2}{ }^{*}=-\frac{\left(\mathrm{X}_{\mathrm{sh}}+\mathrm{X}_{1}\right) \mathrm{V}_{2}{ }^{2}}{\mathrm{X}_{\mathrm{t}}{ }^{2}} \angle 90+ \\
& \frac{\mathrm{X}_{\mathrm{sh}} \mathrm{V}_{1} \mathrm{~V}_{2}}{\mathrm{X}_{\mathrm{t}}^{2}} \angle\left(90+\delta_{2}-\delta_{1}\right)+ \\
& \frac{\mathrm{X}_{1} \mathrm{~V}_{2} \mathrm{~V}_{\mathrm{sh}}}{\mathrm{X}_{\mathrm{t}}^{2}} \angle\left(90+\delta_{2}-\theta_{\mathrm{sh}}\right)+ \\
& \frac{\left(\mathrm{X}_{\mathrm{sh}}+\mathrm{X}_{1}\right) \mathrm{V}_{2} \mathrm{~V}_{\mathrm{ser}}}{\mathrm{X}_{\mathrm{t}}^{2}} \angle\left(90+\delta_{2}-\theta_{\text {ser }}\right) \\
& \mathrm{P}_{2}=\frac{\mathrm{X}_{\mathrm{sh}} \mathrm{V}_{1} \mathrm{~V}_{2}}{\mathrm{X}_{\mathrm{t}}^{2}} \sin \left(\delta_{1}-\delta_{2}\right)-\frac{\mathrm{X}_{1} \mathrm{~V}_{2} \mathrm{~V}_{\mathrm{sh}}}{\mathrm{X}_{\mathrm{t}}{ }^{2}} \sin \left(\delta_{2}-\theta_{\mathrm{sh}}\right) \\
& -\frac{\left(X_{\text {sh }}+X_{1}\right) V_{2} V_{\text {ser }}}{X_{t}^{2}} \sin \left(\delta_{2}-\theta_{\text {ser }}\right) \\
& \mathrm{Q}_{2}=\frac{\left(\mathrm{X}_{\mathrm{sh}}+\mathrm{X}_{1}\right) \mathrm{V}_{2}{ }^{2}}{\mathrm{X}_{\mathrm{t}}^{2}}-\frac{\mathrm{X}_{\mathrm{sh}} \mathrm{V}_{1} \mathrm{~V}_{2}}{\mathrm{X}_{\mathrm{t}}{ }^{2}} \cos \left(\delta_{2}-\delta_{1}\right)- \\
& \frac{\mathrm{X}_{1} \mathrm{~V}_{2} \mathrm{~V}_{\mathrm{sh}}}{\mathrm{X}_{\mathrm{t}}^{2}} \cos \left(\delta_{2}-\theta_{\text {sh }}\right)-\frac{\left(\mathrm{X}_{\mathrm{sh}}+\mathrm{X}_{1}\right) \mathrm{V}_{2} \mathrm{~V}_{\text {ser }}}{\mathrm{X}_{\mathrm{t}}{ }^{2}} \cos \left(\delta_{2}-\theta_{\text {ser }}\right)
\end{aligned}
$$

The UPFC series converter power can be expressed as: 


$$
\begin{aligned}
& \mathrm{P}_{\text {ser }}=-\frac{\mathrm{X}_{\text {sh }} \mathrm{V}_{\text {ser }} \mathrm{V}_{1}}{\mathrm{X}_{\mathrm{t}}^{2}} \sin \left(\theta_{\text {ser }}-\delta_{1}\right)-\frac{\mathrm{X}_{\mathrm{l}} \mathrm{V}_{\text {ser }} \mathrm{V}_{\text {sh }}}{\mathrm{X}_{\mathrm{t}}^{2}} \sin \left(\theta_{\text {ser }}-\theta_{\text {sh }}\right) \\
&+\frac{\left(\mathrm{X}_{\text {sh }}+\mathrm{X}_{1}\right) \mathrm{V}_{2} \mathrm{~V}_{\text {ser }}}{\mathrm{X}_{\mathrm{t}}^{2}} \sin \left(\theta_{\text {ser }}-\delta_{2}\right) \\
& \mathrm{Q}_{\text {ser }}=\frac{\left(\mathrm{X}_{\text {sh }}+\mathrm{X}_{\mathrm{l}}\right) \mathrm{V}_{\text {ser }}^{2}}{\mathrm{X}_{\mathrm{t}}^{2}}+\frac{\mathrm{X}_{\text {sh }} \mathrm{V}_{\text {ser }} \mathrm{V}_{1}}{\mathrm{X}_{\mathrm{t}}^{2}} \cos \left(\theta_{\text {ser }}-\delta_{1}\right)+ \\
& \frac{\mathrm{X}_{\mathrm{l}} \mathrm{V}_{\text {ser }} \mathrm{V}_{\text {sh }}}{\mathrm{X}_{\mathrm{t}}^{2}} \cos \left(\theta_{\text {ser }}-\theta_{\text {sh }}\right)-\frac{\left(\mathrm{X}_{\text {sh }}+\mathrm{X}_{\mathrm{l}}\right) \mathrm{V}_{2} \mathrm{~V}_{\text {ser }}}{\mathrm{X}_{\mathrm{t}}^{2}} \cos \left(\theta_{\text {ser }}-\delta_{2}\right)
\end{aligned}
$$

The UPFC shunt converter power can be expressed as:

$$
\begin{aligned}
& \mathrm{P}_{\mathrm{sh}}= \frac{\mathrm{X}_{2} \mathrm{~V}_{\mathrm{sh}} \mathrm{V}_{1}}{\mathrm{X}_{\mathrm{t}}{ }^{2}} \sin \left(\theta_{\mathrm{sh}}-\delta_{1}\right)+\frac{\mathrm{X}_{\mathrm{I}} \mathrm{V}_{\mathrm{ser}} \mathrm{V}_{\mathrm{sh}}}{\mathrm{X}_{\mathrm{t}}{ }^{2}} \sin \left(\theta_{\mathrm{sh}}-\theta_{\mathrm{ser}}\right) \\
&-\frac{\mathrm{X}_{1} \mathrm{~V}_{2} \mathrm{~V}_{\mathrm{sh}}}{\mathrm{X}_{\mathrm{t}}{ }^{2}} \sin \left(\theta_{\mathrm{sh}}-\delta_{2}\right) \\
& \mathrm{Q}_{\mathrm{sh}}= \frac{\left(\mathrm{X}_{2}+\mathrm{X}_{\mathrm{l}}\right) \mathrm{V}_{\mathrm{sh}}{ }^{2}}{\mathrm{X}_{\mathrm{t}}{ }^{2}}-\frac{\mathrm{X}_{2} \mathrm{~V}_{\mathrm{sh}} \mathrm{V}_{1}}{\mathrm{X}_{\mathrm{t}}{ }^{2}} \cos \left(\theta_{\mathrm{sh}}-\delta_{1}\right)+ \\
& \frac{\mathrm{X}_{1} \mathrm{~V}_{\mathrm{ser}} \mathrm{V}_{\mathrm{sh}}}{\mathrm{X}_{\mathrm{t}}{ }^{2}} \cos \left(\theta_{\mathrm{sh}}-\theta_{\mathrm{ser}}\right)-\frac{\mathrm{X}_{1} \mathrm{~V}_{2} \mathrm{~V}_{\mathrm{sh}}}{\mathrm{X}_{\mathrm{t}}{ }^{2}} \cos \left(\theta_{\mathrm{sh}}-\delta_{2}\right)
\end{aligned}
$$

From (8) to (17) it is obvious that the equation sets of UPFC are highly nonlinear and the effect of every control variable on power flow is not clear. To set the control variables and find the borders of limitations of these variables a visualized presentation of the UPFC control variables is very helpful.

Neglecting UPFC losses, during steady-state operation, the UPFC neither absorbs real power from the system nor injects real power in the system $\left(\mathrm{P}_{\mathrm{ser}}+\mathrm{P}_{\mathrm{sh}}=0\right)$. Physical interpretation of this statement is that the voltage dc link capacitor remains constant at its pre-specified value $\mathrm{V}_{\mathrm{dc}}$. This constraint must be satisfied by the UPFC steady state equations.

The constraint $\mathrm{P}_{\mathrm{ser}}+\mathrm{P}_{\mathrm{sh}}=0$ implies that:

1 -No real power is exchanged between the UPFC and the system; thus, the dc link voltage remains constant.

2-The two voltage sources $\mathrm{V}_{\text {ser }}$ and $\mathrm{V}_{\text {sh }}$ are mutually dependant.

Assuming that variable $\theta_{\text {sh }}$ is assigned to regulate the dc link voltage, power flow (both real and reactive) can be simultaneously controlled/changed by variables $\theta_{\text {ser }}$, $\mathrm{V}_{\text {ser }}$ and $\mathrm{V}_{\mathrm{sh}}$ of the UPFC. Among $\theta_{\text {ser }}, \mathrm{V}_{\text {ser }}$ and $\mathrm{V}_{\mathrm{sh}}$, the control variable of $\theta_{\text {ser has }}$ the most dominant effect on the magnitude of real power flow.

According to the above assumptions it is possible to visualize the effect of UPFC control variables on the power flow through the transmission line. 


\section{EFFECTS OF $\mathrm{V}_{\mathrm{ser}} \angle \theta_{\mathrm{ser}}$ ON SENDING-END, RECEIVING- END AND UPFC POWERS AT CERTAIN TRANSMISSION ANGLE $\delta$ AND SHUNT VOLTAGE SOURCE MAGNITUDE \\ $\mathrm{V}_{\mathrm{SH}}$.}

Figs. (3a through 3d) and Figs. (4a through 4d) show the real and reactive power of the sending-end, receiving-end, UPFC series converter and UPFC shunt converter respectively, versus $\theta_{\text {ser }}$ that changed from $0^{\circ}$ to $360^{\circ}$ at different values of $\mathrm{V}_{\text {ser }}$ from 0 to 0.15 p.u, transmission angle $\delta=25^{\circ}, X_{1}=X_{2}=0.5$ p.u and $V_{\text {sh }}=0.9$ p.u. Figs. (3a) and (3b) show that the sending-end and receiving-end real powers are equals according to the constraint of $P_{\text {ser }}+P_{s h}=0$. This constraint shown in Figs. (3c) and (3d), where $\mathrm{P}_{\text {ser }}=-\mathrm{P}_{\text {sh }}$. Figures $(4 \mathrm{a})$ and $(4 \mathrm{~b})$ show that the sending-end and receiving-end reactive powers are equals at $\mathrm{V}_{\text {ser }}=0$, where in this case $\mathrm{Q}_{\text {ser }}=0$ as shown in Fig. (4c). Figure (4d) shows that UPFC absorb shunt reactive power from the system where $V_{\text {sh }}$ in this case is less than the system voltage. As $\mathrm{V}_{\text {ser }}$ increase, the reactive power in all sides will be changed with the change of $\theta_{\text {ser }}$ in the form of sine wave as illustrated in the previous equations and shown in Figs. (4a) through (4d).
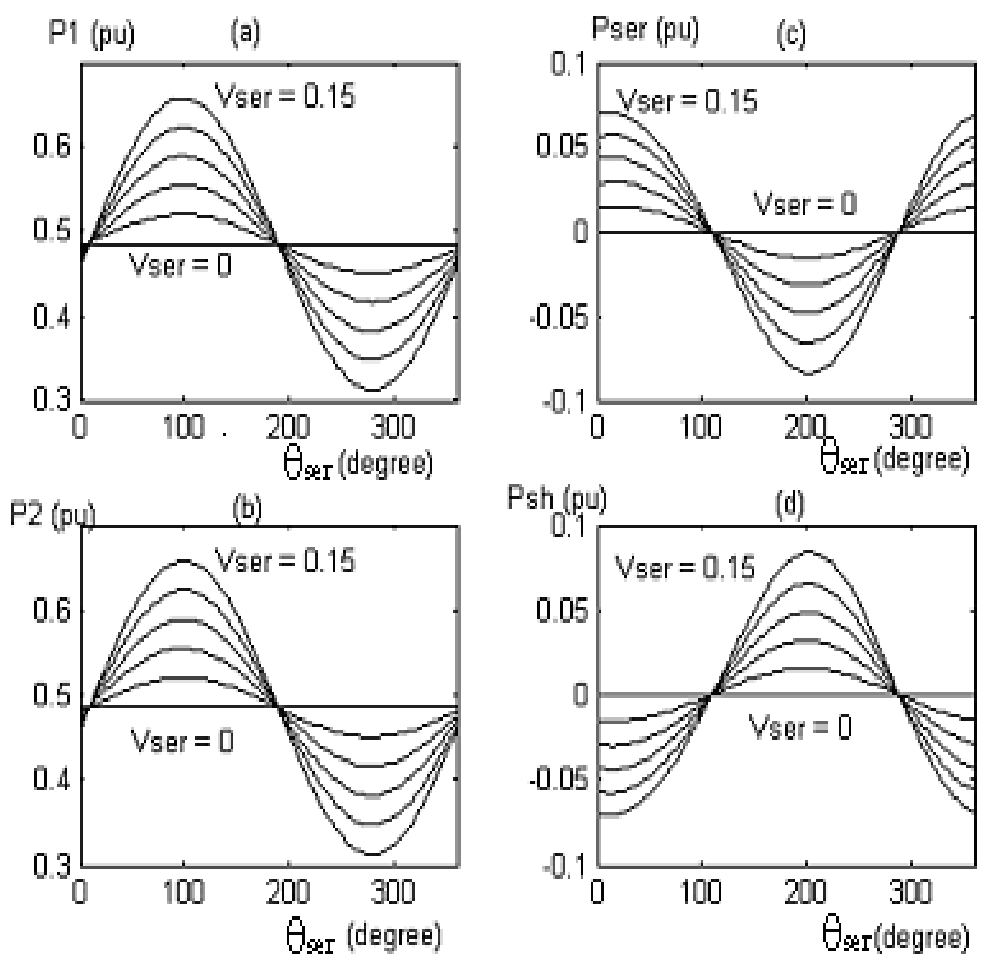

Fig. (3): (a) Sending-end, (b) Receiving-end, (c) Series converter, and (d), Shunt converter, real powers versus $\theta_{\text {ser }}$ at different values of $\mathrm{V}_{\text {ser }}(0-0.15)$ p.u. 

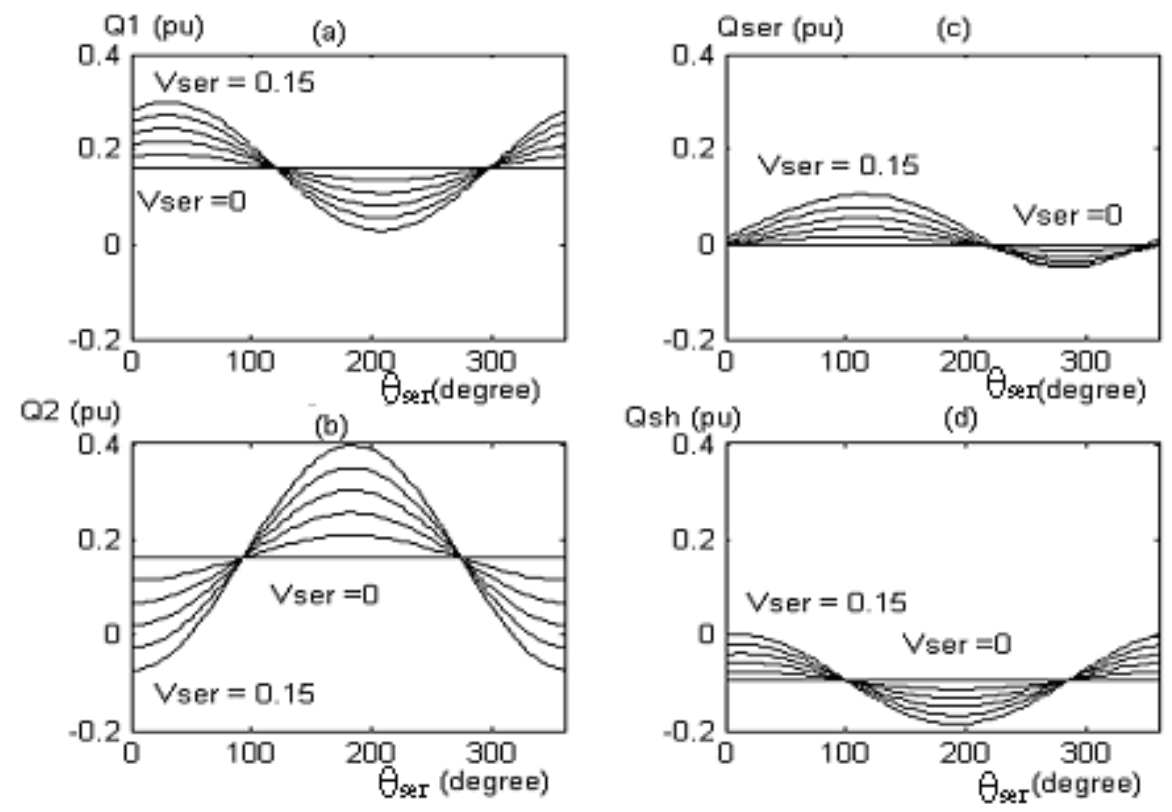

Fig. (4): (a) Sending-end, (b) Receiving-end, (c) Series converter, and (d), Shunt converter, reactive powers versus $\theta_{\text {ser }}$ at different values of $V_{\text {ser }}(0-0.15)$ p.u.

\subsection{Power Flow Characteristics at Sending-End}

When the UPFC is in service, the complex power at the sending-end of the system of Fig. (2) is given by equation (8) that can be decomposed into four components as given by (18).

$\mathrm{S}_{1}=\mathrm{S}_{\mathrm{a}}+\mathrm{S}_{\mathrm{b}}+\mathrm{S}_{\mathrm{c}}+\mathrm{S}_{\mathrm{d}}$

Where $S_{\mathrm{a}}$ to $S_{\mathrm{d}}$ are:

$$
\begin{aligned}
& \mathrm{S}_{\mathrm{a}}=\frac{\left(\mathrm{X}_{\mathrm{sh}}+\mathrm{X}_{2}\right) \mathrm{V}_{1}^{2}}{\mathrm{X}_{\mathrm{t}}^{2}} \angle 90 \\
& \mathrm{~S}_{\mathrm{b}}=-\frac{\mathrm{X}_{\mathrm{sh}} \mathrm{V}_{1} \mathrm{~V}_{2}}{\mathrm{X}_{\mathrm{t}}^{2}} \angle 90+\delta \\
& \mathrm{S}_{\mathrm{c}}=-\frac{\mathrm{X}_{2} \mathrm{~V}_{1} \mathrm{~V}_{\mathrm{sh}}}{\mathrm{X}_{\mathrm{t}}^{2}} \angle 90+\delta-\theta_{\text {sh }} \\
& \mathrm{S}_{\mathrm{d}}=\frac{\mathrm{X}_{\mathrm{sh}} \mathrm{V}_{1} \mathrm{~V}_{\text {ser }}}{\mathrm{X}_{\mathrm{t}}^{2}} \angle 90+\delta-\theta_{\text {ser }}
\end{aligned}
$$

Noting that, $\delta$ in (19) is equal to $\delta_{1}$ and the voltage angle of the receiving-end $\left(\delta_{2}\right)$ is chosen as the reference angle. Figure (5) graphically represents $S_{1}$ in terms of its four components. 


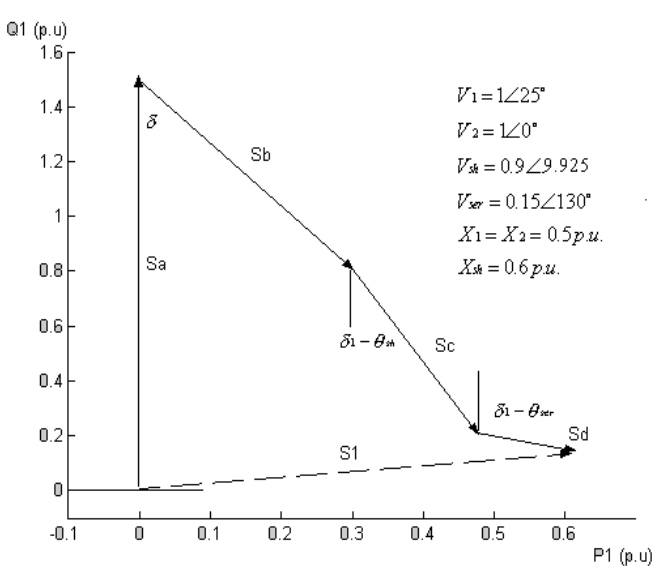

Fig. (5): Graphical representation of $S_{1}$ in the complex power plane.

To visualize the effect of UPFC parameters on tie line power flow, it is possible to rewrite (8) as follows:

$\mathrm{S}_{1}=\mathrm{A}+\mathrm{BV}$ sh $\angle-\theta_{\text {sh }}+\mathrm{CV}_{\text {ser }} \angle-\theta_{\text {ser }}$

Where,

$\mathrm{A}=\mathrm{S}_{\mathrm{a}}+\mathrm{S}_{\mathrm{b}}, \mathrm{B}=-\frac{\mathrm{X}_{2} \mathrm{~V}_{1}}{\mathrm{X}_{\mathrm{t}}{ }^{2}} \angle 90+\delta$, and

$\mathrm{C}=\frac{\mathrm{X}_{\mathrm{sh}} \mathrm{V}_{1}}{\mathrm{X}_{\mathrm{t}}^{2}} \angle 90+\delta$

In this form, the tie line power is expressed by UPFC control variables $\left(\mathrm{V}_{\mathrm{ser}}, \theta_{\mathrm{ser}}, \mathrm{V}_{\mathrm{sh}}\right.$, and $\theta_{\mathrm{sh}}$ ). If system parameters are kept unchanged, $\mathrm{A}, \mathrm{B}$ and $\mathrm{C}$ remain constant. Therefore the tie line power flow becomes only as a function of UPFC control variables.

Now we can visualize the effect of the UPFC control variables on power flow characteristics at sending-end. Figure (6) represents Fig. (5) in the form of (20).

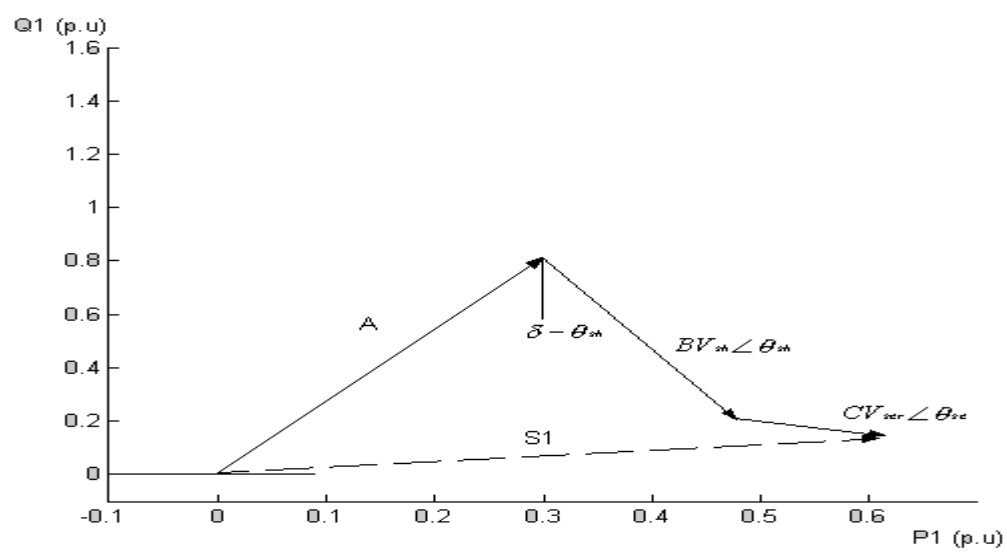

Fig. (6): Graphical representation of $S_{1}$ as a function of UPFC control variables 
As $\theta_{\text {ser }}$ and (or) $\mathrm{V}_{\text {ser }}$ are changed to regulate power flow, $\theta_{\text {sh }}$ is also changed to ensure that $\mathrm{P}_{\text {ser }}+\mathrm{P}_{\mathrm{sh}}=0$. Thus, the tip of vector $\mathrm{S}_{1}$ traces a closed path in the complex power plane of Fig. (6). This closed path is the power diagram of the tie line when the UPFC is in service. To identify the power diagram corresponding to (20), it can be decomposed to real and reactive powers as (22) and (23) respectively.

$$
\begin{aligned}
& \mathrm{P}_{1}=\mathrm{a}-\mathrm{c} \sin \left(\delta-\theta_{\text {ser }}\right) \text { Or } \mathrm{P}_{1}-\mathrm{a}=-\mathrm{c} \sin \left(\delta-\theta_{\text {ser }}\right) \\
& \mathrm{Q}_{1}=\mathrm{b}+\mathrm{c} \cos \left(\delta-\theta_{\text {ser }}\right) \text { Or } \mathrm{Q}_{1}-\mathrm{b}=\mathrm{c} \cos \left(\delta-\theta_{\text {ser }}\right)
\end{aligned}
$$

Squaring equations (23) and (24) then adding them, results in equation (25)

$$
\left(\mathrm{P}_{1}-\mathrm{a}\right)^{2}+\left(\mathrm{Q}_{1}-\mathrm{b}\right)^{2}=\mathrm{c}^{2}
$$

Where:

$$
\begin{aligned}
\mathrm{a}= & \frac{\mathrm{X}_{\mathrm{sh}} \mathrm{V}_{1} \mathrm{~V}_{2}}{\mathrm{X}_{\mathrm{t}}^{2}} \sin (\delta)+\frac{\mathrm{X}_{2} \mathrm{~V}_{1} \mathrm{~V}_{\mathrm{sh}}}{\mathrm{X}_{\mathrm{t}}^{2}} \sin \left(\delta-\theta_{\mathrm{sh}}\right) \\
\mathrm{b}= & \frac{\left(\mathrm{X}_{\mathrm{sh}}+\mathrm{X}_{2}\right) \mathrm{V}_{1}^{2}}{\mathrm{X}_{\mathrm{t}}^{2}}-\frac{\mathrm{X}_{\mathrm{sh}} \mathrm{V}_{1} \mathrm{~V}_{2}}{\mathrm{X}_{\mathrm{t}}^{2}} \cos (\delta)- \\
& \frac{\mathrm{X}_{2} \mathrm{~V}_{1} \mathrm{~V}_{\mathrm{sh}}}{\mathrm{X}_{\mathrm{t}}^{2}} \cos \left(\delta-\theta_{\mathrm{sh}}\right) \\
\mathrm{c}= & \frac{\mathrm{X}_{\mathrm{sh}} \mathrm{V}_{\mathrm{ser}} \mathrm{V}_{1}}{\mathrm{X}_{\mathrm{t}}^{2}}
\end{aligned}
$$

If $\mathrm{a}$ and $\mathrm{b}$ are assumed as constant values, then (25) can represents a circle in the complex power plane. However, in general a and b in (25) can not be assumed as fixed values, since it is function of $\theta_{\mathrm{sh}}$ and $\mathrm{V}_{\mathrm{sh}}$, which in turn are varied as a results of changing $\theta_{\text {ser }}$ and/or $\mathrm{V}_{\text {ser }}$. Thus for different values of $\theta_{\text {ser }}$, there are some different values for $\theta_{\text {sh }}$ as shown in Fig. (7). Fig. (8) shows the variation of the center $(a, b)$ of the closed path due to the change of the series voltage source angle $\left(\theta_{\text {ser }}\right)$. Therefore (25) identifies a closed path, with constant radius c and centers on arc ef as shown in Fig. (9), which illustrates the tie line complex power region for different values of $\theta_{\text {ser }}$ and $\mathrm{V}_{\text {ser. }}$.

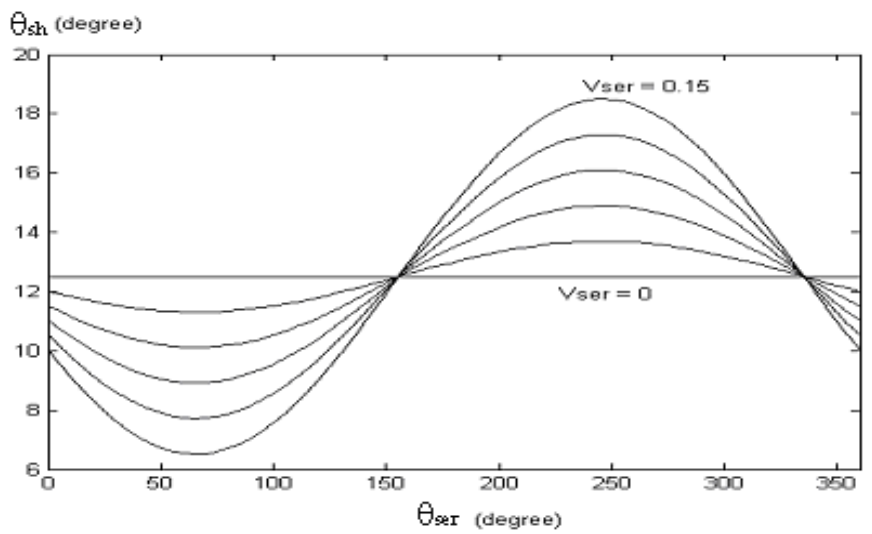

Fig. (7): Variation of ( $\left.\theta_{\text {sh }}\right)$ versus ( $\left.\theta_{\text {ser }}\right)$ at different values of the magnitude of series voltage and $\delta=25^{\circ}$. 


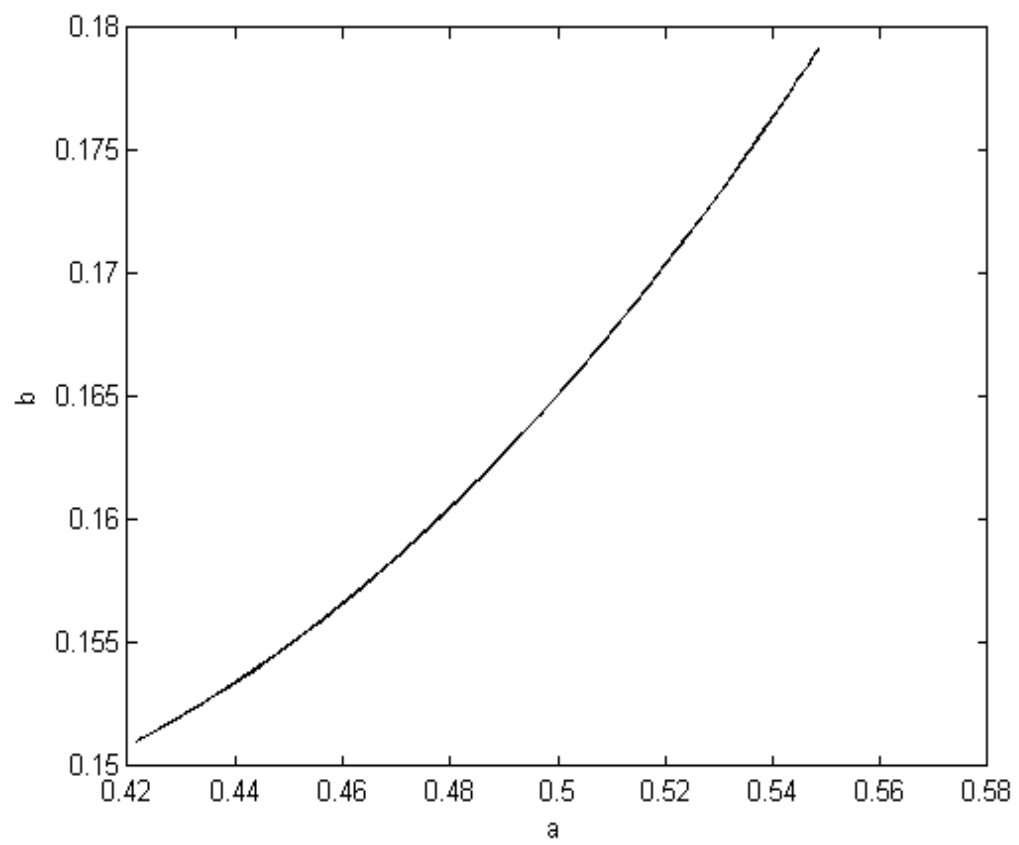

Fig. (8): variation of the center of the closed path $(a, b)$ at different values of $\theta_{\text {ser }}$

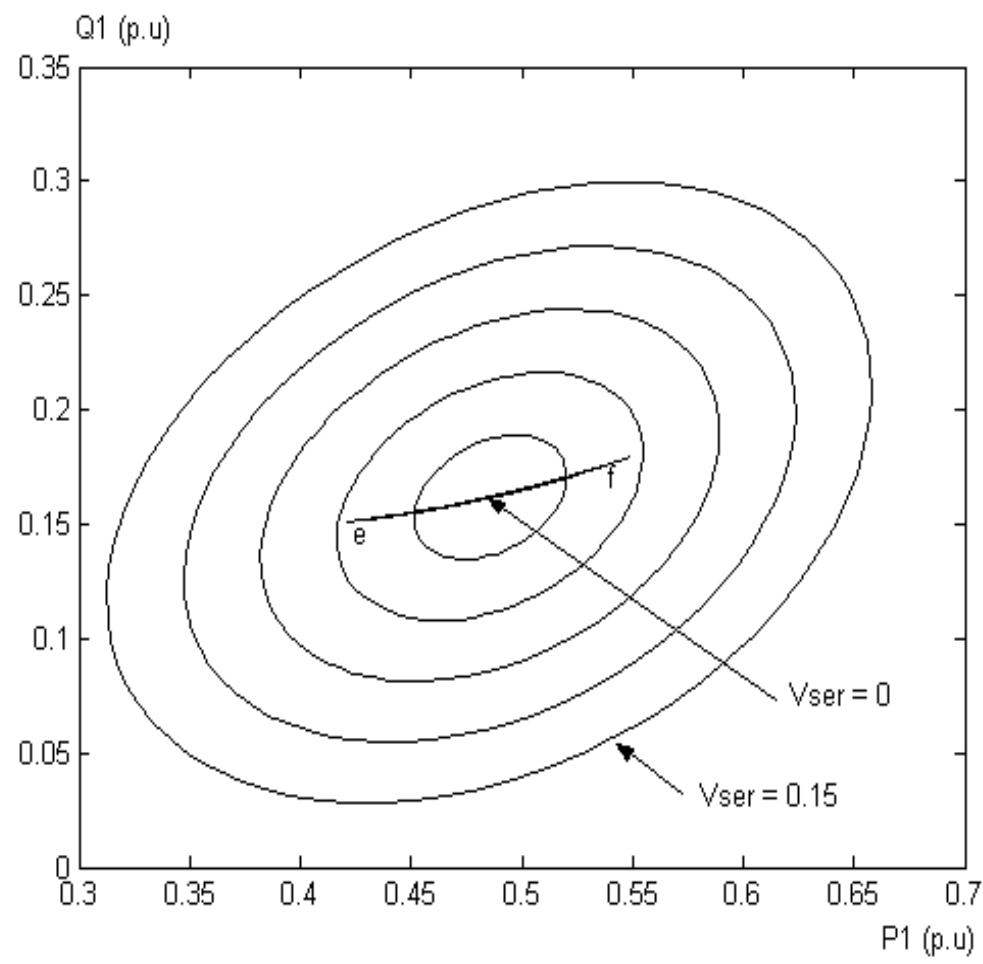

Fig. (9): The tie line complex power region at sending-end 


\subsection{Power Flow Characteristics at Receiving-End}

The power flow characteristics at receiving-end with UPFC connected, can be visualized by rearranged equations (12) and (3) to be in the form of equations (26) and (27)

$\mathrm{P}_{2}=\mathrm{a}+\mathrm{c} \sin \theta_{\text {ser }}$ or $\mathrm{P}_{2}-\mathrm{a}=\mathrm{c} \sin \theta_{\text {ser }}$

$\mathrm{Q}_{2}=\mathrm{b}-\mathrm{c} \cos \theta_{\text {ser }}$ or $\mathrm{Q}_{2}-\mathrm{b}=-\mathrm{c} \cos \theta_{\text {ser }}$

Squaring equations (26) and (27) then adding them, results in equation (28)

$\left(\mathrm{P}_{2}-\mathrm{a}\right)^{2}+\left(\mathrm{Q}_{2}-\mathrm{b}\right)^{2}=\mathrm{c}^{2}$

Where:

$\mathrm{a}=\frac{\mathrm{X}_{\mathrm{sh}} \mathrm{V}_{1} \mathrm{~V}_{2}}{\mathrm{X}_{\mathrm{t}}^{2}} \sin \delta+\frac{\mathrm{X}_{1} \mathrm{~V}_{2} \mathrm{~V}_{\mathrm{sh}}}{\mathrm{X}_{\mathrm{t}}^{2}} \sin \theta_{\mathrm{sh}}$

$\mathrm{b}=\frac{\left(\mathrm{X}_{\mathrm{sh}}+\mathrm{X}_{\mathrm{1}}\right) \mathrm{V}_{2}{ }^{2}}{\mathrm{X}_{\mathrm{t}}{ }^{2}}-\frac{\mathrm{X}_{\mathrm{sh}} \mathrm{V}_{1} \mathrm{~V}_{2}}{\mathrm{X}_{\mathrm{t}}{ }^{2}} \cos \delta-\frac{\mathrm{X}_{1} \mathrm{~V}_{2} \mathrm{~V}_{\mathrm{sh}}}{\mathrm{X}_{\mathrm{t}}{ }^{2}} \cos \theta_{\mathrm{sh}} \quad \mathrm{c}=\frac{\left(\mathrm{X}_{\mathrm{sh}}+\mathrm{X}_{\mathrm{1}}\right) \mathrm{V}_{2} \mathrm{~V}_{\text {ser }}}{\mathrm{X}_{\mathrm{t}}{ }^{2}}$

Noting that $\delta=\delta_{1}$ and $\delta_{2}=0^{\circ}$ i.e. receiving-end is taken as reference.

Also the Q-P characteristics at the receiving-end appears as an ellipse where the radius $\mathrm{c}$ is constant but the center $(\mathrm{a}, \mathrm{b})$ is varied with the variation of $\theta_{\text {sh }}$ that varied according to the variation of $\theta_{\text {ser }}$ to achieve the constraint of $P_{\text {ser }}+P_{s h}=0$. Figure (10) shows the Q-P characteristics at receiving-end at power angle $\delta=25^{\circ}$ for different values of $\theta_{\text {ser }}$ from $0^{\circ}$ to $360^{\circ}$ and $V_{\text {ser }}$ from 0 to 0.15 p.u.

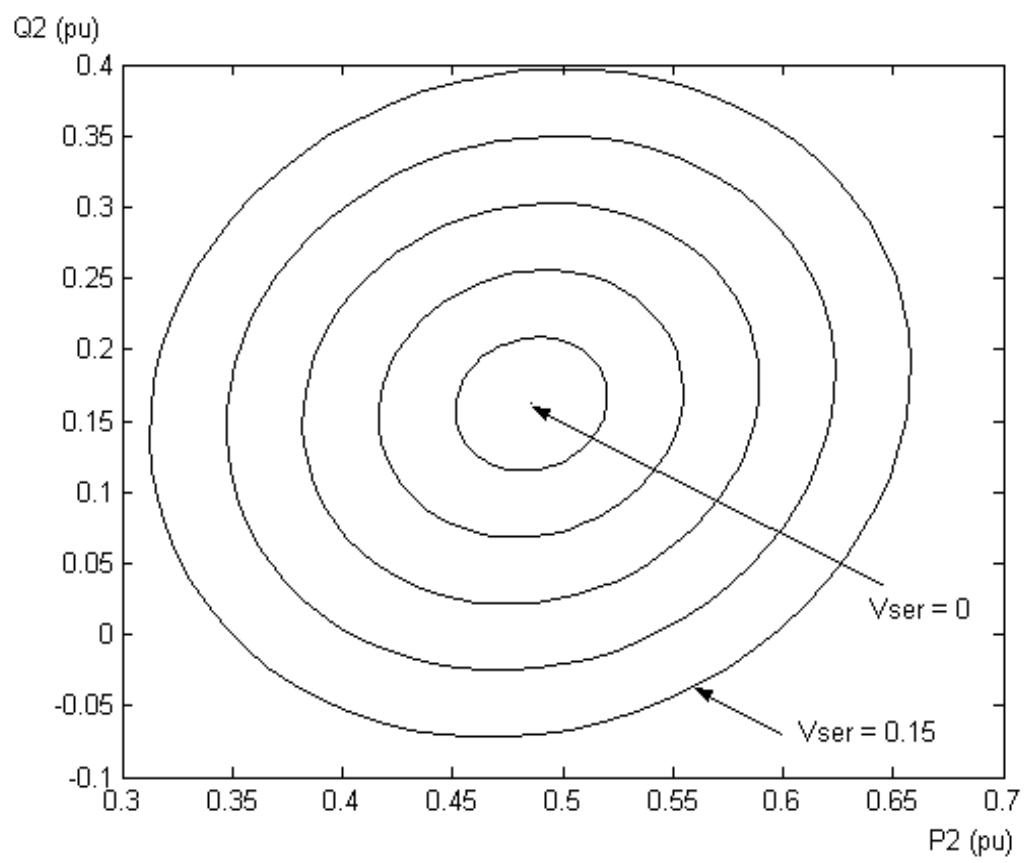

Fig. (10): The tie line complex power region at receiving-end 


\section{EFFECT OF THE SHUNT VOLTAGE SOURCE MAGNITUDE $\mathrm{V}_{\text {SH }}$ ON THE POWER FLOW CHARACTERISTICS}

Figure (11) shows the Q-P characteristics at sending-end for different values of $\mathrm{V}_{\text {sh }}$ (0.9-1.1). This figure emphasize that when $\mathrm{V}_{\mathrm{sh}}$ is larger than the system voltage, the UPFC injects reactive power into the system and vice versa. Also the Q-P curves at different values of $\mathrm{V}_{\mathrm{sh}}$ are parallel and this emphasize that the injected shunt reactive power of UPFC are independent on the series power.

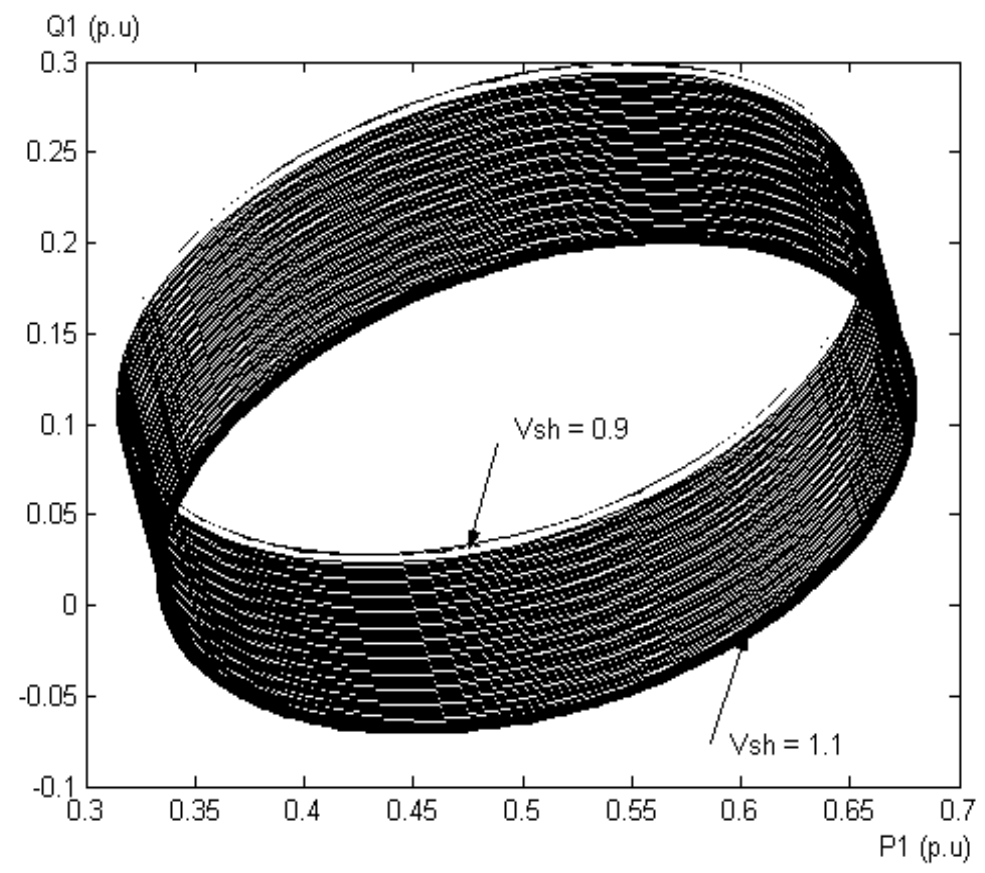

Fig. (11): The tie line complex power region at different values of $\mathrm{V}_{\mathrm{sh}}(0.9-1.1)$ p.u., $\mathrm{V}_{\text {ser }}=0.15$ p.u., and $\delta=25^{\circ}$

\section{EFFECT OF SYSTEM POWER ANGLE ON POWER FLOW CHARACTERISTICS}

The system power angle $\delta$ is another system parameter that can have the significant effect on tie line power transfer when the UPFC is in service. Fig. (1-18) depicts the complex power region that can be controlled by changing $\theta_{\text {ser from }} 0^{\circ}$ to $360^{\circ}$ for two different values of power angle $\delta$. 


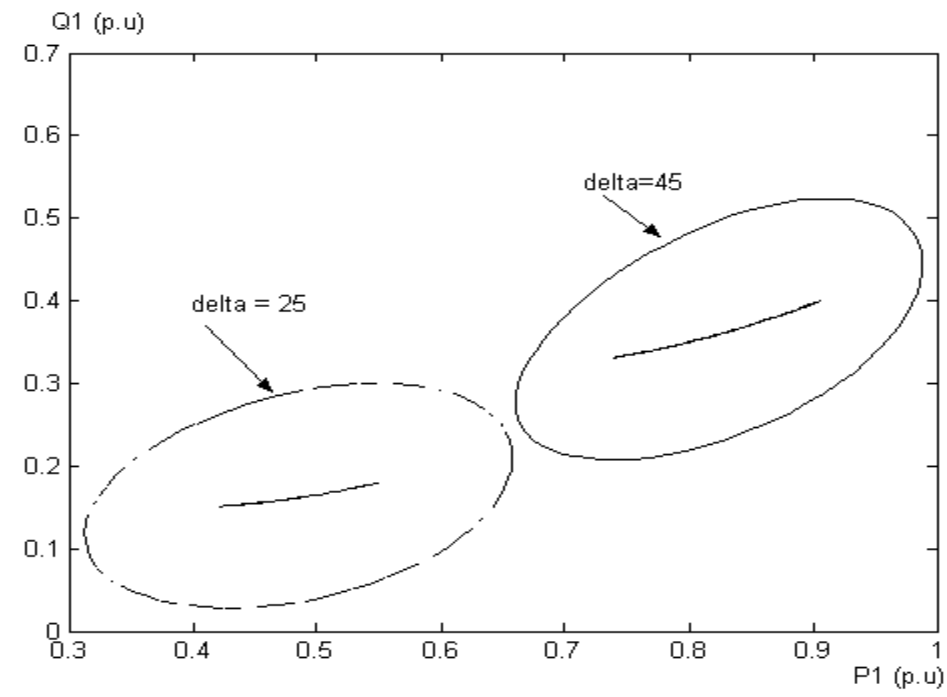

Fig. (12): Sending-end complex power for $\delta=25^{\circ}$ and $\delta=45^{\circ}$.

\section{CONCLUSIONS}

This paper identifies the effect of the UPFC control variables ( $V_{\text {ser }}, \theta_{\text {ser }}, V_{\text {sh }}$, and $\theta_{\text {sh }}$ ) on the line power transfer by using a form of vector presentation in complex power plane. The results show that:

- The amplitude $\mathrm{V}_{\text {ser }}$ and phase angle of series injected voltage $\theta_{\text {ser }}$ have the most effect of real power transfer if the power angle between two systems is small.

- For the large power angle, in addition to $\mathrm{V}_{\text {ser }}$ and $\theta_{\text {ser }}$, the voltage amplitude of the parallel voltage $\mathrm{V}_{\mathrm{sh}}$ can be used for the real power control. However, $\mathrm{V}_{\mathrm{sh}}$ can control the line reactive power for the small power angle.

- The phase angle of parallel voltage $\theta_{\text {sh }}$ is set to regulate the DC link capacitor voltage $\mathrm{V}_{\mathrm{dc}}$.

- The results assure the independency of both series and shunt compensation of the UPFC.

\section{REFERENCES}

1. L. Gyugyi, "A Unified Power Flow Control Concept for Flexible AC Transmission Systems," IEE Proceeding, Vol.139, No.4, July 1992.

2. L. Gyugyi, T.R. Rietman, C. D. Schauder, D. R. Torgerson, S. L. Williams, and A. Edris, "The Unified Power Flow Controller: A New Approach to Power Transmission Control," IEEE Transactions on Power Delivery, Vol.10, No.2 pp. 1085-1092, April 1995.

3. N. G. Hingorani, L. Gyugyi, "Understanding FACTS, Concepts and Technology of Flexible AC Transmission Systems," IEEE Press, 2000. 
4. L. Gyugyi, "Dynamic Compensation of AC Transmission Lines by Solid-State Synchronous Voltage Sources", IEEE/PES Summer Power Meeting, No. 93, Canada, July 1993.

5. S.A. Nabavi-Niaki, M.R. Iravani, "Investigation of Static-shifter Behavior under Steady-State Conditions", ICEE-94, pp. 126-134.

6. S.A. Nabavi-Niaki, "Visualization of UPFC Control Parameters Effects on the Tie-Line Power Flow", Proceeding of LESCOPE 2002, Nova Scotia, Canada, May 2002, pp. 103-107.

7. S.A. Nabavi-Niaki, M. R. Iravani, "Visualization and Investigation of Unified Power Flow Controller (UPFC) Non-Linearity in Power Flow", Power Engineering Society General Meeting, 2003, IEEE, Vol.2 pp. 812-817, July 2003.

\section{نظرة على تأثير منظم مسارات القدرة الموحدة على منحنيات مسارات القدرة}

يهدف البحث إلي دراسة وإلقاء نظرة على تأثير منظم مسارات القدرة الموحدة على منحنيات مسارات القدرة من خلال إدماج المنظم في نظام مكون من باسباران. هذا وقد نم تمثيل منظم مسارات القدرة الموحدة بمصدري جهد مثاليين يتصل بكلٍ منهما ممانعة على التوالي. والنموذج المقدم يلقي الضوء على دلى بلى العلاقة الغير خطية بين منظم مسارات القدرة الموحدة ومشكلة مسارات القدرة أنظمة القوى الكهربية. سوف يتم تمثيل المتغيرات المختلفة لمنظم مسارات القدرة الموحدة, والتى هي أصلاً غير خطية, كمتجة مركب وذلك لإلقاء الضوء ودراسة تأثير مختلف متغيرات التحكم للمنظم على سريان القدرة على الخط. وهذا يساعد في التعريف بتأثيرات كل متغير من متغيرات المنظم على التحكم في القدرة الكهربية 